\title{
Are the Recent Restatements of Financial Institutions 10K's due to the Perceived Earning Volatility Caused by SFAS 161 ?
}

\author{
Veliota Drakopoulou ${ }^{1}$ \\ ${ }^{1}$ MBA, PhD / Assistant Professor, FORBES SCHOOL OF BUSINESS, USA \\ Correspondence: Veliota Drakopoulou, MBA, PhD / Assistant Professor, FORBES SCHOOL OF BUSINESS, \\ USA
}

Received: September 30, 2018

Accepted: October 26, 2018

Online Published: November 2, 2018

doi:10.5430/afr.v7n4p122

URL: https://doi.org/10.5430/afr.v7n4p122

\begin{abstract}
The goal of this research was to investigate the controversy surrounding the inability of SFAS 133 an amendment of SFAS 161 to portray the economics of hedging. This research examined whether or not BHCs' design of hedge effectiveness tests was determined by the concern of the additional earnings volatility possibly evolved from economic hedges that do not qualify for hedge accounting. The results implicate that most BHCs after the amendment of SFAS 161 reassessed their risk management approach to one that is more accounting responsive to ensure that most hedges are highly effective to qualify for hedge accounting. The findings suggest that BHCs reciprocate between risk management and earnings volatility when face a trade-off between employ economic hedges which increase earnings volatility and discontinue economic hedges to avoid increases in earnings volatility. The results accede with the results of Park (2004), Singh (2008), Zhang (2008), Hariom (2014), Bratten (2016), Spencer (2018), and Thomas (2018) who found that derivative users had lower levels of earnings volatility after the introduction of SFAS 161.
\end{abstract}

Keywords: derivatives, accounting for derivatives and hedging activities, economic hedges, fair value hedges, cash flow hedges, SFAS 133, corporate risk management, earnings volatility, earnings smoothing

\section{Introduction}

The Financial Accounting Standards Board (FASB) in an attempt to restore the confidence of investors and corporations in the financial markets as a result of the increased restatements of $10 \mathrm{Ks}$ attributable to errors in derivatives and hedging activities reporting, introduced FASB Statement No. 161, "Disclosures about Derivative Instruments and Hedging Activities - an amendment of FASB Statement No. 133", (Issue Date 03/08). Hariom, Spencer, and Swaminathan (2014) used the derivative disclosures required by SFAS 161 to examine whether the economic consequences and investors' reactions to derivative use vary by the accounting designation firms use for their derivatives and found that hedge designated derivatives are negatively associated with several measures of firm risk, suggesting that the accounting designation of these derivatives captures the intended economic use of these derivatives. Thomas (2018) investigated whether changes in derivative and hedging footnote disclosures required by SFAS 161 affected investor uncertainty and found that uncertainty (measured as the bid-ask spread) is reduced mostly for firms whose disclosures are more affected by SFAS 161. Campbell, Khan, and Pierce (2017) examined whether SFAS's 161 enhanced mandatory derivatives disclosures improved users' understanding of firms' hedging activities, and suggested that enhanced mandatory derivative disclosures helped correct investors' understanding of the implication of unrealized cash flow hedge gains/losses for future firm performance.

In the early 2000s, major financial institutions restated their financial statements due to the enormous inconsistencies in the corporate implementations of SFAS 133. Bratten, Causholli, and Khan (2016) showed that fair value adjustments recorded in OCI during the 2007-2009 financial crisis predicted future profitability, contradicting criticism that fair value accounting forced banks to record excessive downward adjustments. The restatements related to the implementation of hedge accounting under SFAS 133 ascended greatly since 2003 from 514 to about 1,200 corporations in 2005 (Corman,2006). Major financial institutions such as the Bank of America (Note 1), Fannie Mae, and the Federal Home Loan Banks of Dallas, Atlanta and Indianapolis reviewed the accounting treatment for all derivative transactions used as hedges and restated their historical financial statements for the years 2001-2006 since certain transactions did not 
meet strict requirements of the "short cut" method of accounting under SFAS 133. The FASB in response to the increased number of restatements issued in 2007 a proposal to clarify the "Shortcut Method" of hedge accounting: The shortcut method endorses certain preconditions that must be convened for a company to assure that certain hedging relationships of interest rate risk would ensue in no ineffectiveness. Using the shortcut method immensely decreases the required calculations implicated in hedge accounting, as it feigns that the change in value of an interest swap is a "perfect proxy" for the change in value of the hedged item, thereby resulting in no income statement volatility or "ineffectiveness" (FASB News Release, 07/24/07). In the accounting literature Barnes (2001), Park (2004), Bhamornsiri \& Schroeder (2004), and Singh (2008) affirmed that the effects of derivatives and hedging activities were not clear in the financial statements since the gains and losses on those derivatives recognized in financial statements "were deferred from earnings recognition and reported as part of the carrying amount of a related item or as if they were freestanding assets and liabilities" (SFAS 133, 2008, para. 234, p. 106).

Makar, Wang, and Alam (2013) supported the Financial Accounting Standards Board's concern that the SFAS 133 mixed attribute model does not provide the information necessary for investors to understand the net economic effects of derivatives use. The current disclosure requirements in Statement 133 have been criticized for not delivering sufficient information on how derivative and hedging activities affect an entity's financial position, financial performance, and cash flows. Constituents state that under the existing disclosure requirements, it is often difficult to ascertain where and in what amounts derivative instruments and their gains and losses are recorded in the statement of financial position and in the statement of financial performance (SFAS 161, A27). Khan, Li, Rajgopal, and Venkatachalam (2018) examined the cost-effectiveness of the accounting standards issued by the FASB during 1973-2009 from the shareholders' perspective by evaluating the market reactions in relation to agency problems, information asymmetry, proprietary costs, contracting costs, and changes in estimation risk and found that firms with higher levels of information asymmetry, lower contracting costs, and a decrease in estimation risk experience most positive returns.

SFAS 133 as the primary directive for the accounting treatment of derivative instruments in the United States requires all entities to disclose information about the interest rate, foreign exchange rate, and credit risk exposures hedged with derivative instruments. Statement 133 constrains financial institutions to distinguish between derivative instruments designated as hedges used for corporate risk management purposes such as fair value hedges and cash flow hedges and derivative instruments used to hedge economic risks such as economic hedges (SFAS133, 2008, para. 44). One of the most disputable issues in corporate risk management is the proper accounting treatment of hedging activities under SFAS 133. Hedges often generate cash losses and gains, while the transactions they are designed to hedge generate only paper gains and losses (Chance \& Brooks, 2007). If the derivative gains and losses are not reported in the state ment of financial position in unison with the gains and losses of the hedged transactions, the earnings in the income statement would appear increasingly volatile. Spencer (2018) found evidence that firm value has a positive association with the use of hedge accounting and the resulting decrease in earnings volatility.

Hedge accounting reduces earnings volatility by minimizing the potential income statement effect of the risk that is being hedged, since it causes the derivative gains or losses to influence revenues in the period corresponding to the gain or loss consequential to the risk being hedged. The alternative to hedge accounting that is applied to economic or speculative hedges that do not qualify for hedge accounting is to recognize fluctuations in the recorded fair value of derivative hedging instruments immediately in earnings causing the earnings to appear redundantly volatile. The leading purpose of hedging is to diminish erratic earnings changes since earnings volatility and negative earnings surprises are frequently scrutinized by investors and analysts as a warning of unsuccessful company management. Smooth and predictable earnings trends are approvingly prospected by investors and analysts and augment the repute of a competent company management. A hedging policy that curtails inconsistent earnings changes can be advantageous for both directors and the stockholders of a company (Tromblem, 2003). The hedging accounting rules of SFAS 133 lead to ominous earnings volatility which makes the decision to hedge anchored in the company's willingness to accept or not the likelihood of earnings volatility (Kolbasovsky, 2009; Hughen, 2010; Kolbasovsky, 2009; Sigrist, 2008; Trombley, 2003). Spencer specifically (2018) found that the use of hedge accounting is pervasive and that firms' use of hedge accounting is associated with not only the economic motives behind the derivative use, but also the costs and benefits specific to implementing hedge accounting. The author concluded that firms significantly decrease earnings volatility via hedge accounting. 
This study extends the corporate risk management behavior of Bank Holding Companies (BHCs) in the framework of SFAS 133 as amended by SFAS 161 in 2008, by investigating BHCs' hedging activities to find possible differences in earnings volatility related to the timing of the amount of gains and losses recognized in income on derivative hedging instruments for accounting versus economic hedgers (SFAS 133, 2008, para. 17-35). To determine whether or not BHCs reassessed their corporate risk management approach, BHCs were classified as either SFAS161- Accounting Hedgers, or SFAS161- Compliant Hedgers. BHCs are classified as SFAS161-Accounting Hedgers when they use only derivatives qualifying for hedge accounting under SFAS 161 comprising those instruments designated as fair value and cash flow hedges. Alternatively, BHCs are classified as SFAS161-Compliant Hedgers when they use both derivative instruments designated as fair value and cash flow hedges under SFAS 161 and economic hedges that do not qualify for hedge accounting under SFAS 161.The focus of this research is on BHCs since the derivatives market activity in the United States is monopolized by the five largest BHCs, which constitute $97 \%$ of the total notional derivative contracts (OCC, 2009). Also, the banking industry is at the center of the dispute over the relative benefits of fair-value based income measures because banks' balance sheets are comprised almost entirely of financial instruments (Hodder, Hopkins, \& Wahlen, 2006).

\section{Hedge Accounting and Earnings Volatility under SFAS 161}

SFAS 133 requires all derivatives to be reported on the statement of financial position at fair value as either assets or liabilities. Fair value is based on published stock prices or on pricing models or discounted cash flow estimates when stock prices are not published. Under Statement 133 the gains or losses derived from changes in the fair value of a derivative hinge on whether the derivative has been designated as a hedging instrument and is in a qualifying hedging relationship (SFAS161, 205D). For a derivative designated as hedging the exposure to changes in the fair value of a recognized asset, liability or a firm commitment the gain or loss is recognized in earnings in the period of change together with the offsetting loss or gain on the hedged item attributable to the risk being hedged. The effect of that accounting is to reflect in earnings the extent to which the hedge is effective or not in achieving offsetting changes in fair value (SFAS 133, para.18). Since, the main purpose of hedging is to protect the income statement from the effect of adverse changes in prices, interest rates, or currency exchange rates, companies would like to use derivative instruments that qualify for hedge accounting to cause the gain or loss from the derivative to impact earnings in the same period as the gain or loss resulting from the risk being hedged.

The FASB's decision to eliminate the ability to hedge by risk and require entities to assess effectiveness based upon total change in fair value of a hedged item/transaction considerably influences companies' most common hedging strategies since derivatives are usually designated to hedge certain risks and hedging all risks might not be a practical alternative (Sigrist, 2008). The Board supported that "some characteristics of risk management are arduous to differentiate from speculation or position-taking and those speculative activities should not be afforded special accounting" (SFAS133, 2008, para. 352, p. 128). SFAS 133 allows firms to apply hedge accounting and defer on income any gains (losses) from changes in the fair value of derivative instruments designed as hedges after the completion of the hedge (SFAS 133, 2008, para. 363). To meet the requirements of hedge accounting the fair value variations of derivative instruments must neutralize the fair value or cash flow variations of the hedged item/transaction (SFAS 133, 2008, para. 21).

Economic or speculative hedges do not qualify for hedge accounting and they have to recognize fluctuations in the recorded fair value of derivative hedging instruments immediately in earnings. The approach of accelerating the earnings recognition of economic or speculative hedges that do not qualify for hedge accounting reproduces unrepresentative earnings volatility. Frestad and Beisland (2015) argued that SFAS 133 hedge effectiveness is not a trustworthy indication of a speculative constituent in a derivative portfolio so the "highly effective" hedge assessment cannot efficiently distinct economic or speculative hedges from derivative portfolios. Nan (2007) showed through a specific agency model that the early recognition of the use of derivatives who do not qualify for hedge accounting may change the risk allocation in the manager's compensation and motivate speculation.

Contributing to the corporate risk management literature Suh (2007) argued that the hedging disclosures of SFAS 133 did not provide a clear picture of whether companies' earnings volatility intensifications originated from speculative hedges or from economic hedges. Geczy, Minton, and Schrand (2007) disputed that information available in the financial statements regarding companies' corporate hedging risk with derivatives was insufficient to provide investors with the speculating notion of the company. Sigrist (2008) contested that hedge accounting is not reflective 
of the way companies manage risk and produces misleading financial statements results since companies who do not qualify for hedge accounting would include in the income statement fair value fluctuations for risks not hedged distorting earnings and concealing their intended risk management strategy.

Allayannis, Rountree, and Weston (2008) documented that financial statement volatility is costly and directly affects a firm's value. Trombey (2003) in the same spirit attested that most financial institutions attempt to decrease earning volatility with hedging since negative earnings surprises signal an incompetent corporate risk management and are viewed negatively by investors and analysts. Wang (2005) documented that, although bad and good earnings news (as measured by the square of standardized unexpected earnings [SUE] increased future return volatility, bad earnings news raised future volatility more than good earnings news did. Empirical accounting researchers found that after the implementation of SFAS 133 derivatives users had lower levels of earnings volatility and higher levels of income smoothing proposing that SFAS 133 may have driven companies' earnings management decisions (Singh, 2008; Park, 2004; Zhang, 2009; Zhou, 2009).

\section{Hypothesis Development}

SFAS 133 hedge effectiveness protects the income statement from any volatility instigated from variations in the derivatives interest rate, foreign exchange rate, and credit risk underlying. Hedge accounting equalizes the gains and losses on the derivative instrument and the hedged item syncing them in earnings in the same accounting period and only the hedge ineffectiveness between the gains and losses on the derivative instrument and the hedged item are reported directly in income causing adverse volatility. In the existing accounting literature Singh (2008), Park (2004), Zhang (2009), Beneda (2013), and Drakopoulou (2015) recognized that after the original pronouncement of SFAS 133, derivatives users had lower levels of earnings volatility. Beneda (2013) found a strong association between the low reported earnings volatility and the firm use of derivative instruments for hedging. Drakopoulou (2015) originated that bank holding companies (BHCs) which increased the level of accounting hedges and decreased the level of economic hedges experienced a significant decrease in earnings volatility relative to pre-SFAS 133. Hughen (2010) examined a sample of firms that restated previously issued financial statements due to errors in hedge accounting and found that $25 \%$ of firms qualified for SFAS 133 hedge accounting succeeding the restatement maintaining the stability of accounting earnings while $75 \%$ of firms did not qualify for hedge accounting after the restatement since they focused on economic earnings.

While the effects of SFAS 133 on earnings volatility is of pertinent concern, Zhang (2008) indicated the importance of disaffiliating the effects of SFAS 133 on BHCs corporate risk management behavior and immediate earnings volatility while making the presumption that BHCs did not adopt an accounting responsive risk management strategy. Zhang (2008) came to the conclusion, that after the implementation of SFAS 133, financial analysts would not detect any additional earnings volatility if BHCs felt that any additional earnings volatility would be detrimental and material and attuned their derivatives contracts in anticipation of these detriments. Singh (2008) concluded that, after the original pronouncement of SFAS 133, the intensification given to hedging and smoothing conferred managers' intentions to avoid increases in earnings volatility through earnings smoothing. Park (2004) argued that BHCs either overstated the impact of SFAS 133 on earnings volatility to ease the formation of SFAS 133 or they already had attuned their hedging strategies in expectancy of earnings volatility amplifications. Park's (2004) tests of earnings volatility showed that the "three income-affecting sources (TIPs) (i.e., ineffective hedge gains/losses, gains/losses excluded in hedge assessment, and effects from cancelled forecasted transactions previously designed as cash flow hedges)" (p. 15) arisen from SFAS 133 did not increase earnings volatility and concluded that variations in the fair value of derivative instruments not qualifying for hedge accounting might had an effect on earnings volatility increases.

Therefore, to determine whether some BHCs adjusted their corporate risk management strategy to one that is more accounting responsive to achieve a decrease in earnings volatility, the following research question and associated hypothesis is proposed:

Did BHCs that increased their level of SFAS161-Accounting Hedges and decreased their level of SFAS161-Economic Hedges in response to the new accounting standard experience a significant decrease in earnings volatility relative to pre-SFAS 133 ?

$\mathrm{H}_{1}$ : There was no difference in earnings volatility for SFAS161-Compliant Hedgers and SFAS161-Accounting Hedgers after the 2008 amendment of SFAS 133.

$\mathrm{H}_{1 \mathrm{a}}$ : There was a difference in earnings volatility for SFAS161-Compliant Hedgers and SFAS161-Accounting Hedgers after the 2008 amendment of SFAS 133. 


\section{Sample, Research Method, and Results}

The derivatives market in the United States is controlled by the five largest BHCs which represent $97 \%$ of the total financial industry's notional amount of derivatives (OCC, 2009). The primary data examined in this study are for U.S. BHCs in Peer 1 and Peer 2 Groups with total assets greater than $\$ 10$ and $\$ 3$ billion respectively. The data for the derivative instruments and hedging activities of the sampled BHCs were collected from their annual financial statements (10Ks) found in the Edgar Filing System of the SEC by using the open full reader search and keyword searches such as notional, cash flow hedges, fair value hedges, economic hedges, derivatives, and SFAS 133 from fiscal year 2008 to fiscal year 2009. The years 2008 and 2009 were selected because SFAS No. 133 was amended in 2008 by SFAS 161 (Issue Date 03/08) changing the disclosures about derivative instruments and hedging activities. In the BHCs official website under investor relations, data for the CEOs stock option-based compensation were retrieved from the BHCs proxy statements, while data on the number of analysts following the company were retrieved under analyst coverage.

\subsection{Descriptive Statistics}

SFAS 133 requires entities to recognize all of its derivative instruments in its statement of financial position as either assets or liabilities depending on the rights or obligations under the contracts. All derivative instruments shall be measured at fair value (SFAS 133, para.17). The accounting for changes in the fair value (that is, gains or losses) of a derivative depends on whether it has been designated and qualifies as part of a hedging relationship and, if so, on the reason for holding it. Gains and losses on derivative instruments are accounted for as follows: (a). Economic hedge: The gain or loss on a derivative instrument not designated as a hedging instrument shall be recognized currently in earnings; (b). Fair value hedge: The gain or loss on a derivative instrument designated and qualifying as a fair value hedging instrument as well as the offsetting loss or gain on the hedged item attributable to the hedged risk shall be recognized currently in earnings in the same accounting period; and (c). Cash flow hedge: The effective portion of the gain or loss on a derivative designated as a cash flow hedge is reported in other comprehensive income and reclassified into earnings in the same period or periods during which the hedged forecasted transaction affects earnings while the ineffective portion is reported in earnings (SFAS 133, para.18 \& 30).

This study extends the corporate risk management behavior of Bank Holding Companies (BHCs) in the framework of SFAS 133 as amended by SFAS 161 in 2008, by investigating BHCs' hedging activities to find possible differences in earnings volatility related to the timing of the amount of gains and losses recognized in income on derivative hedging instruments for Accounting versus Economic Hedgers. The hedging activities of SFAS161-Compliant and Accounting Hedgers were researched to investigate whether BHCs manipulated the differential treatment of the changes in the fair value of derivatives designated as hedging instruments (cash flow hedges, fair value hedges, and economic hedges) to smooth earnings and decrease earnings volatility in an attempt to increase the intrinsic value of their stock. Descriptive statistics for the 2008 and 2009 classification of hedging instruments designated as Cash Flow Hedges, Fair Value Hedges, and Economic Hedges is presented in Table 1 for SFAS161-Compliant Hedgers including the timing of recognition in income of the gains and losses on hedging instruments and the reported ineffectiveness in hedging relationships for accounting vs. economic hedges.

For SFAS161-Compliant Hedgers the results in Table 1 suggest that for cash flow hedging instruments, the 2009 amount of (a) gain recognized in OCI on derivative $(\mathrm{M}=3.16, \mathrm{SD}=2.85)$, (b) gain recognized from AOCI into income ( $\mathrm{M}=2.12, \mathrm{SD}=1.20)$, and (c) gain reclassified in income on derivative (ineffective portion) $(\mathrm{M}=2.04, \mathrm{SD}$ $=1.65$ ), were higher than the 2008 amount of (a) loss recognized in OCI on derivative $(\mathrm{M}=-3.60, \mathrm{SD}=1.68)$, (b) loss recognized from AOCI into income $(\mathrm{M}=-3.07, \mathrm{SD}=1.07)$, and (c) loss reclassified in income on derivative (ineffective portion) $(\mathrm{M}=-8.71, \mathrm{SD}=6.73)$. For fair value hedging instruments the results suggest that the 2009 amount of (a) gain recognized in income on derivative $(\mathrm{M}=1.98, \mathrm{SD}=2.68)$, and (b) loss recognized in income on derivative (ineffective portion) $(\mathrm{M}=-6.02, \mathrm{SD}=5.16$ ), were lower than the 2008 amount of (a) gain recognized in income on derivative $(\mathrm{M}=7.80, \mathrm{SD}=3.32)$, and (b) loss recognized in income on derivative (ineffective portion) (M $=-9.20, \mathrm{SD}=2.28$ ). For economic hedges the results suggest that the 2009 amount of (a) gain recognized in income on derivative $(\mathrm{M}=3.08, \mathrm{SD}=9.89)$, were lower than the 2008 amount of (a) gain recognized in income on derivative $(\mathrm{M}=8.00, \mathrm{SD}=2.31)$.

The results in Table 1 show that for cash flow hedges the ineffective portion of the amount of gain (loss) recognized in income on derivatives for 2009 is a gain of 0.20 million while for 2008 is a loss of -0.87 million. For fair value hedges the ineffective portion of the amount of gain (loss) recognized in income on derivative for 2009 is a loss of -0.60 million while for 2008 is a loss of -0.90 million. For economic hedges the amount of gain (loss) recognized in income on derivative for 2009 is a gain of 0.30 million while for 2008 is a gain of 0.80 million. 
SFAS161-Compliant Hedgers adjusted their hedging behavior in 2009 and re-designated their hedges to overstate their income with derivatives converging more for the economic benefits of hedging and tormenting less for earnings volatility. These results are consistent with Liu, Seow, and Xie's (2011) findings that SFAS 133 hedge ineffectiveness is beneficial for evaluating the corporate risk management activities of BHCs because banks with significant hedge ineffectiveness gains or losses are considered riskier since they are exposed to higher variations in interest rates, they have a higher credit default risk, and lower return rates.

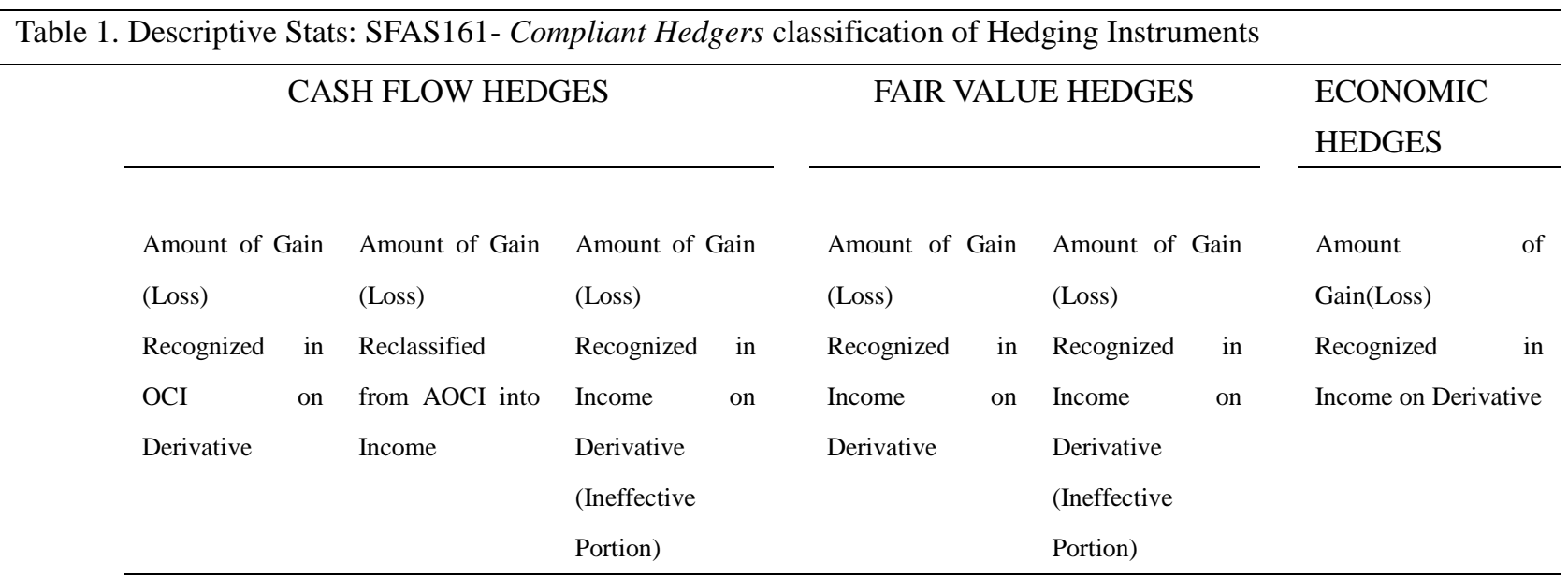

SFAS 161 Compliant Hedgers

\begin{tabular}{|c|c|c|c|c|c|c|c|c|c|c|c|c|}
\hline & 2009 & 2008 & 2009 & 2008 & 2009 & 2008 & 2009 & 2008 & 2009 & 2008 & 2009 & 2008 \\
\hline $\mathrm{N}$ & 24 & 24 & 24 & 24 & 24 & 24 & 14 & 13 & 10 & 9 & 24 & 24 \\
\hline M & 3.167 & -3.608 & 2.127 & -3.075 & 2.04 & -8.71 & 1.986 & 7.080 & -6.020 & -9.200 & 2.690 & 5.990 \\
\hline $\mathrm{SD}$ & 2.853 & 1.689 & 1.201 & 1.071 & 1.65 & 6.73 & 2.608 & 3.320 & 5.162 & 2.880 & 9.892 & 2.311 \\
\hline Min & -6.915 & -3.231 & -8.140 & -4.542 & -3.59 & -3.15 & 5.600 & -7.840 & -1.052 & -8.585 & -7.827 & -2.991 \\
\hline Max & 8.540 & 6.013 & 4.022 & 9.480 & 7.03 & 6.90 & 7.802 & 6.800 & 1.127 & 1.770 & 3.620 & 1.069 \\
\hline SEM & 5.824 & 3.449 & 2.451 & 2.185 & 3.37 & 1.37 & 6.971 & 9.200 & 1.632 & 9.580 & 2.019 & 4.718 \\
\hline Q1 & -0.010 & -1.735 & -1.403 & -2.963 & -1.00 & 0.00 & 2.165 & 2.450 & -3.300 & -1.00 & -5.435 & 3.525 \\
\hline Mdn & 0.000 & 0.000 & 7.500 & 0.000 & 0.00 & 0.00 & 5.065 & 3.430 & -5.100 & 9.00 & 6.515 & 2.265 \\
\hline
\end{tabular}

For SFAS161-Accounting Hedgers the results in Table 2 suggest that for cash flow hedging instruments the 2009 amount of (a) gain recognized in OCI on derivative $(\mathrm{M}=8.49, \mathrm{SD}=2.89)$, (b) gain recognized from AOCI into income ( $\mathrm{M}=1.43, \mathrm{SD}=1.19)$, and (c) gain reclassified in income on derivative (ineffective portion) $(\mathrm{M}=2.25, \mathrm{SD}$ $=1.05$ ), were higher than the 2008 amount of (a) gain recognized in OCI on derivative $(\mathrm{M}=1.07, \mathrm{SD}=3.26)$, (b) gain recognized from AOCI into income $(\mathrm{M}=1.03, \mathrm{SD}=1.86)$, and (c) gain reclassified in income on derivative (ineffective portion) $(\mathrm{M}=0.24, \mathrm{SD}=1.84)$. For fair value hedging instruments the results suggest that the 2009 amount of: (a) gain recognized in income on derivative $(\mathrm{M}=9.83, \mathrm{SD}=1.56)$, were higher than the 2008 amount of (a) gain recognized in income on derivative $(M=4.50, S D=2.61)$, while the 2009 amount of (b) loss recognized in income on derivative (ineffective portion) $(\mathrm{M}=-2.20, \mathrm{SD}=2.12)$, were lower than the 2008 amount of (b) gain recognized in income on derivative (ineffective portion) $(\mathrm{M}=2.40, \mathrm{SD}=6.03)$. 


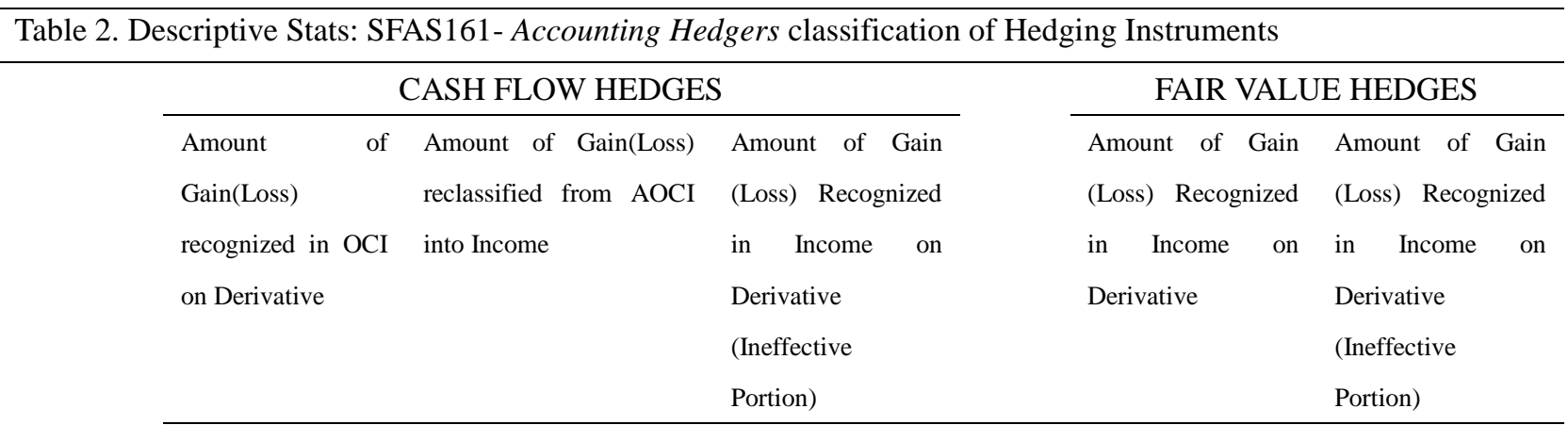

SFAS161- Accounting Hedgers

\begin{tabular}{|c|c|c|c|c|c|c|c|c|c|c|}
\hline & 2009 & 2008 & 2009 & 2008 & 2009 & 2008 & 2009 & 2008 & 2009 & 2008 \\
\hline $\mathrm{N}$ & 38 & 38 & 38 & 38 & 38 & 37 & 18 & 17 & 8 & 8 \\
\hline M & 8.490 & 1.079 & 1.438 & 1.0315 & 2.254 & 0.241 & 9.831 & 4.506 & -2.209 & 2.400 \\
\hline SD & 2.890 & 3.265 & 1.193 & 1.863 & 1.056 & 1.848 & 1.563 & 2.610 & 2.128 & 6.030 \\
\hline Min & -5.360 & -8.512 & -3.547 & -8.519 & -6.200 & -9.380 & 1.330 & -3.436 & -4.660 & -1.200 \\
\hline Max & 8.200 & 1.752 & 5.234 & 5.400 & 6.010 & 3.280 & 5.681 & 8.202 & 3.170 & 1.720 \\
\hline SEM & 4.690 & 5.297 & 1.936 & 3.022 & 1.712 & 3.038 & 3.683 & 6.331 & 7.523 & 2.130 \\
\hline Q1 & 0.000 & 0.000 & 0.000 & 0.000 & 0.000 & 0.000 & 9.560 & -2.960 & -1.725 & 1.500 \\
\hline Mdn & 1.940 & 3.500 & 1.750 & 6.250 & 0.000 & 0.000 & 2.415 & 1.270 & -6.000 & 4.000 \\
\hline Q3 & 2.430 & 3.467 & 1.985 & 5.962 & 0.000 & 0.100 & 1.000 & 6.320 & 1.248 & 8.000 \\
\hline
\end{tabular}

For SFAS161-Accounting Hedgers the descriptive statistics in Table 2 show that for cash flow hedges the ineffective portion of the amount of gain (loss) recognized in income on derivative for 2009 is a gain of 0.22 million while for 2008 is a gain of 0.24 . For fair value hedges the ineffective portion of the amount of gain (loss) recognized in income on derivative for 2009 is a loss of -0.22 while for 2008 is a gain of 0.24 . SFAS133-accounting hedgers adjusted their hedging behavior in 2009 and de-designated their hedges in an attempt to understate earnings volatility by discontinuing economic hedges and realizing more desirable accounting results.

Descriptive statistics in Table 3 posit that there is a significant difference in earnings volatility for SFAS161-Accounting Hedgers and SFAS161-Compliant Hedgers in 2009 one year after the 2008 amendment of SFAS 133. Earnings volatility is measured by the coefficient of variation of earnings over four quarters before and after the 2008 amendment of SFAS 133 (Barnes, 2001; Barton, 2001; Zhang, 2008), and the coefficient of variation of earnings is measured as the average standard deviation of the ratio of total earnings before taxes and loan loss provisions to average total assets (Laeven et al., 2009). The earnings volatility for SFAS161-Accounting Hedgers is 0.46 billion in 2009 and the earnings volatility for SFAS161-Compliant Hedgers is 1.38 billion in 2009, indicating that the earnings volatility for SFAS133-Compliant Hedgers is three times higher the earnings volatility for SFAS161-Accounting Hedgers. This implies that BHCs who increased the level of accounting hedges and decreased or discontinued the level of economic hedges in response to the 2008 amendment of SFAS 133 experienced a significant change in earnings volatility. 
Table 3. Descriptive Stats: Dependent Variable-- EVOL for SFAS161 AHs \& CHs

\begin{tabular}{|c|c|c|c|c|}
\hline & \multicolumn{2}{|c|}{ SFAS-161 Accounting Hedgers } & \multicolumn{2}{|c|}{ SFAS-161 Compliant Hedgers } \\
\hline & EVOL 2009 & EVOL 2008 & EVOL 2009 & EVOL 2008 \\
\hline $\mathrm{N}$ & 38 & 38 & 24 & 24 \\
\hline M & 0.46 & 0.80 & 1.38 & 1.76 \\
\hline SD & 1.63 & 2.19 & 1.77 & 3.21 \\
\hline MIN & 1.97 & 1.24 & 5.20 & 2.08 \\
\hline MAX & 8.74 & 1.24 & 6.97 & 1.12 \\
\hline SEM & 2.65 & 3.56 & 3.62 & 0.65 \\
\hline $\mathrm{Q}_{1}$ & 3.51 & 3.59 & 1.56 & 1.36 \\
\hline Mdn & 7.39 & 8.15 & 8.23 & 5.57 \\
\hline $\mathrm{Q}_{3}$ & 1.40 & 0.34 & 1.55 & 1.10 \\
\hline
\end{tabular}

This study by separating the effects of SFAS 161 on earnings volatility and BHCs corporate risk-management behavior concluded that the apprehension of earnings volatility caused by economic hedges under SFAS 133 led SFAS161-Accounting Hedgers and SFAS161-Compliant Hedgers to adjust their hedging behavior to one that is more accounting responsive. As a result of discontinuing economic hedges SFAS161-Accounting Hedgers experienced less volatility in earnings, while SFAS161-Compliant Hedgers just by moderating the use of economic hedges experienced more volatile earnings. Consistent with the findings of Zhang (2009), Singh (2008), and Park (2004) the results of this study show that after the 2008 amendment of SFAS 133 BHCs exhibited a more accounting responsive corporate risk management approach in apprehension of the increased earnings volatility caused by economic hedges.

These results are consistent with Zhou's (2011) findings that the earnings recognition of fair value hedge ineffectiveness under SFAS 133 "improves the value and risk relevance of accounting earnings" (p.27) while the informational content of the ineffective portion of the gains/losses recognized in income on derivative is higher for BHCs since they have more expertise in corporate risk management modus operandi giving them a comparative advantage over nonfinancial firms. While the impact of SFAS 133 on earnings volatility has become an increasing concern in the accounting literature, Zhang (2008) argued that it is important to disaffiliate the effects of SFAS 133 on BHCs corporate risk management behavior and earnings volatility assuming that BHCs did not adopt an accounting responsive risk management strategy.

After the original pronouncement of SFAS 133, Zhang (2008) supposed that financial analysts would not detect any additional earnings volatility if BHCs felt that any additional earnings volatility would be detrimental and material and attuned their derivatives contracts in anticipation of these detriments, while Singh (2008) concluded that the intensification given to hedging and smoothing conferred managers' intention to avoid increases in earnings volatility through earnings smoothing. In the same token, Park (2004) argued that BHCs either overstated the impact of SFAS 133 on earnings volatility to ease the formation of SFAS 133 or they already had attuned their hedging strategies in expectancy of earnings volatility amplifications.

\subsection{Paired T-Tests}

This research investigated whether or not there was a difference in earnings volatility for SFAS161-Compliant Hedgers and SFAS161-Accounting Hedgers after the 2008 amendment of SFAS 133. A univariate comparison between SFAS161- Accounting Hedgers and SFAS161-Compliant Hedgers were performed to test whether or not BHCs that increased their level of SFAS161-accounting hedges and decreased their level of SFAS161-economic hedges in response to the new accounting standard experienced a significant decrease in earnings volatility relative to pre-SFAS 133. Based on the univariate results if the mean value of earnings volatility of SFAS161- compliant hedgers is less than or equal to that of SFAS161-Accounting Hedgers (at the alpha $=0.05$ level) as determined by a one-tailed t-test, then earnings volatility was not due to economic hedges. If the mean value of earnings volatility of SFAS161-Compliant Hedgers is higher than SFAS161-Accounting Hedgers, then BHCs earnings volatility resulted from economic hedges. 
To investigate whether or not BHCs that increased their level of SFAS161 accounting hedges and decreased their level of economic hedges in response to the 2008 amendment of SFAS 133 experienced a significant change in earnings volatility, paired sample $t$ - tests were conducted to compare the mean earnings volatility of SFAS161-Compliant Hedgers and SFAS161-Accounting Hedgers. Table 4 provides the t test results of the difference between the 2009/2008 mean earnings volatility of the two groups of BHCs. The t- test revealed that there was a statistically significant difference between the mean earnings volatility of the two groups, $t(60)=2.09, p \leq .05$ (two-tailed test). The mean earnings volatility of "SFAS161-accounting hedgers" $(\mathrm{M}=0.46, \mathrm{SD}=1.63)$ was lower than the mean earnings volatility of "SFAS161-compliant hedgers" $(\mathrm{M}=1.38, \mathrm{SD}=1.73)$, hence this is an indication that BHCs' earnings volatility resulted from economic hedges.

Table 4. Results of t-tests for 2008/2009 EVol, HEDGEINF ${\text { CASHFLOw, and HEDGEINF } \text { FAIRVALUE, }_{\text {ECOHEDGE }} \text { Gain(Loss) }}$ for $\mathrm{AH}$ and $\mathrm{CH}$

\begin{tabular}{|c|c|c|c|c|c|c|c|c|c|c|c|}
\hline \multirow[b]{2}{*}{ Outcome } & \multicolumn{2}{|c|}{$\mathrm{AH}$} & \multirow[b]{2}{*}{$\mathrm{n}$} & \multicolumn{2}{|c|}{$\mathrm{CH}$} & \multirow[b]{2}{*}{$\mathrm{n}$} & \multirow[b]{2}{*}{$\begin{array}{c}95 \% \text { CI for Mean } \\
\text { Difference }\end{array}$} & \multirow[b]{2}{*}{$\mathrm{r}$} & \multirow[b]{2}{*}{$\mathrm{t}$} & \multirow[b]{2}{*}{$p$} & \multirow[b]{2}{*}{$d f$} \\
\hline & M & SD & & M & SD & & & & & & \\
\hline EVol & 0.46 & 1.63 & 38 & 1.38 & 1.73 & 24 & $(.92)$ & $.44^{*}$ & 2.09 & .049 & 60 \\
\hline HEDGEINF $_{\text {CASHFLOW }}$ & 0.23 & 1.06 & 38 & 0.20 & 1.65 & 24 & 0.272 & $.37 *$ & $(.07)$ & .090 & 35 \\
\hline HEDGEINF $_{\text {FAIRVALUE }}$ & $(.46)$ & 0.92 & 38 & (.56) & 3.94 & 24 & $(0.1)$ & $.16^{*}$ & $(.07)$ & .090 & 48 \\
\hline
\end{tabular}

$* \mathrm{p} \geq 0.05$ (two-tailed test). EVol: The average standard deviation of the ratio of total earnings before income taxes and loan loss provisions to

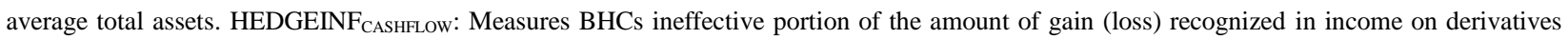
designated as cash flow hedges. HEDGEINFFAIRVALUE: Measures BHCs ineffective portion of the amount of gain (loss) recognized in income on derivatives designated as fair value hedges;

According to the extant accounting literature, income statement earnings volatility is either caused by the cash flow hedge ineffectiveness and/or fair value hedge ineffectiveness of SFAS 133 accounting hedges or it is caused by economic hedges. To further disentangle the effects of SFAS 133 accounting hedges and economic hedges on earnings volatility, a paired sample $t$ test were conducted to compare the mean ineffective amount of the gains (losses) recognized in income on derivatives designated as cash flow hedges (HEDGEIN cash flow hedges), fair value hedges (HEDGEIN fair value hedges, and economic hedges (NETGains (Losses) for both "SFAS161-Compliant Hedgers" and "SFAS161-Accounting Hedgers."

Table 5 provides the $t$ test results of the mean difference between the 2009 cash flow hedge ineffectiveness of the two groups of BHCs. The $t$ test revealed that there was not a significant difference in the 2009 cash flow hedge ineffectiveness of "SFAS161-Compliant Hedgers" $(\mathrm{M}=0.20, \mathrm{SD}=1.65)$ and "SFAS161-accounting hedgers" (M=0.23, $\mathrm{SD}=1.06$ ), conditions; $\mathrm{t}(35)=-0.07, \mathrm{p} \geq 0.05$ (two-tailed test).

Table 5. Two-Sample t-test: Difference in Cash Flow Hedge Ineffectiveness between CHs \& AHs

\begin{tabular}{lllll}
\hline 2009 & $\mathrm{~N}$ & $\mathrm{M}$ & $\mathrm{SD}$ \\
& & & \\
\hline SFAS161 Accounting Hedgers $(\mathrm{AH})$ & 38 & 0.23 & 1.06 \\
SFAS161 Compliant Hedgers $(\mathrm{CH})$ & 24 & 0.20 & 1.65
\end{tabular}

difference $(\mathrm{AH}-\mathrm{CH})=0.272$

standard error of difference $=0.37$

$t$ test of difference $=\mathrm{H} 0: \mu 1-\mu 2=0: \mathrm{t}=-0.07, \quad p=.09, \quad d f=35$

Table 6 provides the $t$ test results of the mean difference between the 2009 fair value hedge ineffectiveness of the two groups of BHCs. The t- test revealed that there was not a significant difference in the 2009 fair value hedge ineffectiveness of "SFAS161-compliant hedgers" $(\mathrm{M}=-0.56, \mathrm{SD}=3.04)$ and "SFAS161-Accounting Hedgers" $(\mathrm{M}=$ $-0.46, \mathrm{SD}=0.92$ ), conditions; $\mathrm{t}(48)=-0.06, \mathrm{p} \geq 0.05$ (two-tailed test). 
Table 6. Two-Sample t-test: Difference in Fair Value Hedge Ineffectiveness between CHs \& AHs

\begin{tabular}{lccc}
\hline 2009 & $\mathrm{~N}$ & $\mathrm{M} D$ & \\
\hline SFAS161 Accounting Hedgers $(\mathrm{AH})$ & 38 & -0.46 & 0.92 \\
SFAS161 Compliant Hedgers $(\mathrm{CH})$ & 24 & -0.56 & 3.94 \\
difference $(\mathrm{AH}-\mathrm{CH})=-0.1$ & & & \\
standard error of difference $=0.1631$ & & & \\
$t$ test of difference $=\mathrm{H} 0: \mu 1-\mu 2=0: \mathrm{t}=-0.07, \quad p=.09, \quad d f=48$ &
\end{tabular}

Table 7 provides the $t$ test results of the mean difference between the 2009 and 2008 gains or (losses) recognized by SFAS161- compliant hedgers in income on derivative instruments designated as economic hedges. The t test revealed that there was a significant difference in the 2009 economic hedges NETGain(Loss) $(\mathrm{M}=0.26, \mathrm{SD}=0.98)$ and the 2008 economic hedges NETGain(Loss) $(\mathrm{M}=0.59, \mathrm{SD}=2.13)$ of "SFAS133-compliant hedgers," conditions; $\mathrm{t}(33)=$ $-0.70, \mathrm{p} \leq 0.05$ (two-tailed test).

Table 7. Two-Sample t-test: 2009/2008 Difference in Economic Hedges Net Gain/(Loss) of CHs

\begin{tabular}{lccc}
\hline 2009/2008 & $\mathrm{N}$ & $\mathrm{M}$ & $\mathrm{SD}$ \\
\hline SFAS161 Compliant Hedgers $(\mathrm{CH})$ & 25 & 0.26 & 0.98 \\
SFAS161 Compliant Hedgers $\quad(\mathrm{CH})$ & 25 & 0.59 & 2.13 \\
& & & \\
difference $(\mathrm{CH} 2009-\mathrm{CH} 2008)=-0.33$ & & & \\
standard error of difference $=0.47$ & & \\
$t$ test of difference $=\mathrm{H} 0: \mu 1-\mu 2=0: \mathrm{t}=-0.70, \quad p=.0003, \quad d f=33$
\end{tabular}

$* \mathrm{p} \geq 0.05$ (two-tailed test). ECOHEDGE $E_{\text {Gain(Loss) }}$ : Measures both realized and unrealized gains and losses recognized in income due to changes in fair value of derivatives designated as economic hedges

The t-test results in Table 5 reveal that the 2009 mean cash flow hedge ineffectiveness is 2.04 million for SFAS133-compliant hedgers and 2.31 million for SFAS161-compliant hedgers. There is not a significant difference in the cash flow hedge ineffectiveness of SFAS161-compliant hedgers and SFAS161-accounting hedgers since $\mathrm{p} \geq$ 0.05. The $t$ test results in Table 6 reveal that the 2009 mean fair value hedge ineffectiveness is -0.56 million for SFAS161-compliant hedgers and -0.46 million for SFAS133-compliant hedgers. There is not a significant difference in the fair value hedge ineffectiveness of SFAS161-compliant hedgers and SFAS161-accounting hedgers since $\mathrm{p} \geq$ 0.05. The $t$ test results in Table 7 reveal that the mean amount of gain recognized in income on derivatives designated as economic hedges is 0.26 million in 2009 and 0.59 million in 2008 for SFAS161-compliant hedgers. There is a significant difference in the 2009 and 2008 amount of economic hedges NETGain (Loss) of SFAS161-compliant hedgers since $\mathrm{p} \leq 0.05$, indicating that SFAS161-compliant hedgers reduced the amount of gain recognized in income by economic hedges by $50 \%$ in 2009 .

The results of the t- tests indicate that income statement earnings volatility is caused by economic hedges since there is no difference in the mean cash flow and fair value hedge ineffectiveness of SFAS161-compliant hedgers and SFAS161-accounting hedgers. The results are consistent with Nan (2007) which claims that SFAS 133 with the early recognition requirement intends to detain speculative activities through financial derivatives. The author argues that companies who are engaged in speculative activities through financial derivatives experience more volatile earnings "caused by the early recognition of unrealized gains/losses, while firms who effectively hedge through financial derivatives do not have this adverse effect in earnings" (p.14). Park's (2004) tests of earnings volatility shows that the "three income-affecting sources (TIPs) (i.e., ineffective hedge gains/losses, gains/losses excluded in hedge assessment, and effects from cancelled forecasted transactions previously designed as cash flow hedges) arisen from SFAS 133 did not increase earnings volatility" (p. 15). 


\subsection{Multiple Regression Analysis}

Singh's (2008) modified regression model is used to test the relationship of SFAS161-Accounting Hedgers' and SFAS161- Compliant Hedgers' hedging activities and earnings volatility. Using Singh's (2008) regression model, the mean earnings volatility derived from BHCs derivative instruments designated as fair value hedges, cash flow hedges, and economic hedges is regressed against the corporate risk management control variables that proxy for the hedging incentives of the two groups. These control variables proxied for financial distress, managerial risk aversion, underinvestment costs, information asymmetry, and the regulatory capital adequacy of BHCs based on prior literature on theoretical corporate risk management (Adkins, Carter \& Simpson, 2007; Boyabatli \& Toktay, 2004; Muller, Verschoor, 2008; Pai, Curcio \& Thornton, 2006). Earnings volatility is measured by the coefficient of variation of earnings one year before and after the 2008 amendment of SFAS 133 following Bartons' (2001), Barnes' (2001), and Zhangs' (2008) prior research. Zhang (2008) imposed eight quarters of non-missing data as the lowest possible data condition to lessen the noise in estimating earnings volatility. Laeven and Levine (2009) defined the coefficient of variation of earnings as the average standard deviation of the ratio of total earnings before taxes and loan loss provisions to average total assets.

According to the extant accounting literature, the income statement effect of hedging activities under SFAS 133 depends upon whether a derivative instrument has been designated as a fair value, cash flow hedge or economic hedge. If the derivative is designated as a fair value or cash flow hedge, only the ineffective portion of the hedging gains/losses is recognized in current earnings causing reluctant volatility, while for economic hedges both realized and unrealized gains and losses from changes in fair value of derivatives are recorded in earnings causing more volatile earnings. For highly effective hedges variations in the fair value of derivative instruments and the underlying hedged items mainly offset each other causing not material hedge ineffectiveness and leading to significant lower earnings volatility (Coughlan, 2003). To disentangle the effects of SFAS 133 on earnings volatility caused by economic or accounting hedges two control variables were added in the multiple regressions. These two control variables are HEDGEINF and NETGains (Losses). HEDGEINF measures BHCs value of cash flow and fair value cash ineffectiveness, while NETGains (Losses) measures both the realized and unrealized gains and losses due to changes in fair value of economic hedges recorded in earnings.

The Multiple regression model below was used to test if the corporate risk management incentives of SFAS161-compliant hedgers and SFAS161-accounting hedgers to hedge using accounting vs. economic hedges significantly predicted any possible earnings volatility on their financial statements.

EVolit $=\beta 0+\beta 1$ Notionalit $+\beta 2$ ESmoothit $+\beta 3$ ESmoothlit $+\beta 4$ FINLEVit $+\beta 5$ CapAdeq1 it $+\beta 6$ UNDERC it + $\beta 7 I N F O A S Y i t+\beta 8 M N G R i s k i t+\beta 9 I R L i b o r+\beta 10 H E D G E I N F i t+\beta 11 N E T G a i n s($ Losses) $i t+\varepsilon i t$

A definition of the variables utilized in this research is presented in Appendix A.

Table 8 presents the multiple regression results of the Hypotheses. The results of the regression indicated that the combination of the variables explained $48 \%$ of the variance in earnings volatility for SFAS161-accounting hedgers $(\mathrm{R} 2=.478, \mathrm{~F}(10,27)=2.47, \mathrm{p}<.005)$, while they explained $70 \%$ of the variance in earnings volatility for SFAS133-compliant hedgers $(\mathrm{R} 2=.678, \mathrm{~F}(10,13)=2.74, \mathrm{p}<.005)$.

SFAS161-Accounting Hedgers. The regression was employed to help determine which of the eleven corporate-risk management hedging variables could be used to predict the Earnings Volatility of SFAS161-Accounting Hedgers one year after the amendment of the SFAS133. The variables produced a coefficient of determination R2 of .993 (F (10, $27)=3.00, \mathrm{p}=.8)$ for the prediction of Earnings Volatility $(\mathrm{EVol})$. The predictor with the lowest non-significant regression coefficient (HEDGEIN fair value, $\quad=.18, \mathrm{t}(\mathrm{df}=26)=42.6, \mathrm{p}=1.37)$ was removed and the final regression analysis conducted had a coefficient of determination R2 of .478 $(\mathrm{F}(10,27)=2.47, \mathrm{p}=.03)$, with four significant predictors of Earnings Volatility (EVol) -- ESmooth2, FINLEV, INFOASY, and MNGRisk. Together, these four predictors explained $48 \%$ of the variation in earnings volatility for SFAS133-accounting hedgers. The strongest predictor was INFOASY ( $\mathrm{p}=.0063)$, followed by ESmooth2 $(\mathrm{p}=.0173)$, FINLEV $(\mathrm{p}=.0187)$, and MNGRisk $(p=.0301)$. INFOASY $(\beta=1.0937, t=2.965)$ and ESmooth2 $(\beta=0.0487, t=2.544)$ were both positively related to EVol, while FINLEV $(\beta=-0.4758, \mathrm{t}=-2.502)$ and MNGRisk $(\beta=-3.5257, \mathrm{t}=-2.289)$ were both negatively related to EVol. Finally, tests for multicollinearity indicated that a very low level of multicollinearity was present (VIF = 1.503 for INFOASY, 2.374 for ESmooth2, 1.513 for FINLEV, and 1.583 for MNGRisk).

SFAS161-Compliant Hedgers. Multiple regression analysis was used to test if the corporate-risk management hedging variables significantly predicted the Earnings Volatility of SFAS161-Compliant Hedgers in 2009 one year after the amendment of SFAS133. The variables produced a coefficient of determination R2 of $.695(\mathrm{~F}(12,11)=$ 
$2.09, \mathrm{p}=.10)$ for the prediction of Earnings Volatility $(\mathrm{EVol})$. The predictors with the highest VIF coefficients (HEDGEIN fair value, VIF=5.416 \& NOTIONAL, VIF=5.068) were removed from the regression since a VIF value greater than 5 indicates that some degree of multicollinearity exists with respect to these two variables. The final regression analysis conducted had a coefficient of determination R2 of.678 $(F(10,13)=2.74, p=.04)$, with two significant predictors of Earnings Volatility (EVol) -- INFOASY, and HEDGEIN cash flow. The predictors explained $67 \%$ of the variation in earnings volatility for SFAS161-Compliant Hedgers. The strongest predictor was HEDGEIN cash flow $(\mathrm{p}=.0076)$ followed by INFOASY $(\mathrm{p}=.05)$. HEDGEIN cash flow $(\beta=0.6742, \mathrm{t}=3.156)$ and INFOASY $(\beta=1.8149, t=2.063)$ were both positively related to EVol. Finally, tests for multicollinearity indicated that a very low level of multicollinearity was present for HEDGEIN cash flow (VIF = 1.605) and INFOASY (VIF=1.814)

Table 8. Regression Analysis for Variables Predicting Earnings Volatility

\begin{tabular}{|c|c|c|c|c|c|c|}
\hline \multirow[t]{2}{*}{ NOTIONAL } & \multicolumn{2}{|c|}{ ACCOUNTING HEDGERS } & \multirow[t]{2}{*}{$2 S$} & \multicolumn{3}{|c|}{ COMPLIANT HEDGERS } \\
\hline & $\mathrm{B}$ & SE B & & B & SE B & $\beta$ \\
\hline \multicolumn{7}{|l|}{ Variables } \\
\hline NOTIONAL & -1.2979 & 1.2957 & -1.2979 & & & \\
\hline ESmooth & -0.3641 & 0.4876 & -0.3641 & 0.1790 & 0.1023 & 0.6418 \\
\hline ESmooth1 & 0.1625 & 0.1566 & 0.1625 & 0.2880 & 0.4772 & 0.6605 \\
\hline FINLEV & -0.4758 & 0.1901 & -0.4758 & -0.1210 & 0.2739 & -0.9018 \\
\hline INFOASY & 1.0937 & 0.3688 & 1.0937 & 0.0560 & 0.2537 & 0.6097 \\
\hline UNDERC & -0.0344 & 0.3060 & -0.0344 & -0.2420 & 0.3562 & -0.7080 \\
\hline MNGRisk & -0.3525 & 1.5405 & -0.3525 & 0.7180 & 0.7216 & 1.9351 \\
\hline CapAdeq1 & 0.1658 & 0.1164 & 0.1658 & -0.2890 & 0.9756 & 0.2015 \\
\hline IRLIBOR & -0.0136 & 0.1258 & -0.0136 & -0.3800 & 0.2103 & 0.2153 \\
\hline HEDGEIN cash flow & 0.2593 & 0.2830 & 0.2593 & 0.6970 & 0.1465 & 0.7471 \\
\hline HEDGEIN fair value & & & & 0.2440 & 0.2459 & 1.3379 \\
\hline NETGains(Losses) & & & & -0.069 & 0.3927 & 0.1245 \\
\hline
\end{tabular}

The multiple regression analysis shows that the most significant determinants for earnings volatility are information asymmetry for SFAS161-Accounting Hedgers and hedge ineffectiveness for SFAS161-Compliant Hedgers. SFAS 133 vanguard increased earnings volatility for SFAS161-Compliant Hedgers since they engage in risk management strategies that are driven by both the economic and the accounting benefits of hedging. Although, firm valuations have traditionally been negatively related to earnings volatility, SFAS161-Compliant Hedgers should not worry that their stock price will be devalued because of the additional earnings volatility arising from economic hedges. Given hedging is uniform with a logical risk management strategy that is clearly presented in the financial statements, investors and analysts have denoted that they will appraise companies based on an economic and not an accountingdriven analysis. The regression analysis results suggest that SFAS161- Accounting Hedgers converging exclusively on hedge accounting disregarding the economics of hedging will be viewed more inauspiciously by investors than SFAS161-Compliant Hedgers that focus on both the economics and the accounting of hedging.

Couglan (2003) suggested that SFAS 161-Accounting Hedgers converging exclusively on hedge accounting disregarding the economics of hedging will be viewed more inauspiciously by investors than SFAS161-Compliant Hedgers that focus on both the economics and the accounting of hedging. The author believes that BHCs should engage investors more on their risk management policy and demonstrate that their hedging strategy is effectively administered, examined, and managed, while Willis (2002) recommended that BHCs with increased earnings volatility should educate investors about the causes by voluntarily disclosing in their financial statements additional 
information regarding their hedging activities to assist analysts recognize the impact of economic hedges and accounting hedge ineffectiveness on earnings volatility. Panaretou, Shackleton, and Taylor (2009) argued that eminent "information regarding derivative instruments and hedges lessens the noise contained in earnings" (p. 6), reducing analysts' forecasted errors and lowering the information asymmetry between analysts and BHCs.

\section{Conclusion}

This study suggest that apprehension of earnings volatility caused by economic hedges under SFAS 133, led SFAS161-Compliant Hedgers to adjust their hedging behavior to attain more desirable accounting results by drastically reducing the use of economic hedges and subsequently reducing the amount of gains (losses) recognized in income on derivative instruments designated as economic hedges. This is an implication that BHCs facing a trade-off between employing economic hedges which increase earnings volatility and discontinuing economic hedges to avoid increases in earnings volatility, reciprocate between risk management and earnings volatility while suffering increases in market risk exposure (Kolbasovsky, 2009).Coughlan (2003) suggested that the implementation of hedging decisions should balance both economic and accounting performance. This translates into BHCs validating the economic benefits and parallel assessing whether or not a hedging instrument would qualify for SFAS 161 hedge accounting. BHCs should consider the impact of economic hedges on earnings volatility alongside with the impact of hedging instruments that do or do not qualify for SFAS 161 hedge accounting. Campell et.al (2017) suggest that the enhanced mandatory derivative disclosures required by SFAS 161 improved investors' understanding of the effects of derivative and hedging activities on future firm performance and firm value - and consequently mitigated investor mispricing.

The results of this research accede with the results of Singh (2008), Park (2004), Zhang (2008), Hariom (2014), Bratten (2016), Spencer (2018), and Thomas (2018) who found that derivative users had lower levels of earnings volatility after the introduction of SFAS 161. Given that the major purpose of hedging is to shelter the income statement from variations in interest rates, foreign-exchange rates, or credit rates, SFAS161-Accounting Hedgers exercising derivatives for hedging reassessed their risk management approach to one that is more accounting responsive to ensure that most hedges are highly effective to qualify for hedge accounting. Hedge accounting reduces earnings volatility by minimizing the potential income statement effect of the risk that is being hedged since it causes the derivative gains or losses to influence earnings in the corresponding period as the gains or losses ensued from the risk being hedged.

The alternative to hedge accounting that is applied to derivatives designated as economic hedges is to recognize variations in the recorded fair value of the derivative instrument immediately in earnings causing redundant volatility in earnings (Coughlan, 2003). Income statement earnings volatility is caused by either the cash flow or fair value hedge ineffectiveness of SFAS 133 accounting hedges or economic hedges according to the extant accounting literature (Nan, 2007; Park, 2004; Singh, 2008; Tromblem, 2003; Zhang, 2008; Hariom, 2014; Bratten, 2016; Spencer 2018; and Thomas, 2018). For SFAS 133 fully effective accounting hedges, changes in the fair value of the hedging instrument precisely offset changes in the fair value of the hedged item ascribed to the hedged risk and are realized in earnings in the same accounting period (SFAS 133, 2008, para. 18) protecting the income statement from the earnings volatility resulting from changes in the fair value of the derivative instrument (Tromblem, 2003), while any difference occurring from the gains/losses on the hedging instrument that do not offset the loss/gain on the hedged item ascribed to the hedged risk is the effect of hedge ineffectiveness and it is immediately recognized in earnings creating earnings volatility (SFAS 133, 2008, para. $21 \& 22$ ).

This research compliments recent research by Hariom et al., (2014) and Campbell et all. , (2017) who showed that disclosure of firms' accounting designation helps investors to better price derivative gains according to their underlying economic use. It is concluded that even when hedging relationships are highly-effective they still might not be perfect into offsetting changes in the fair value of the hedged item and the hedging instrument causing the ineffective portion of the change in the fair value of the hedging instrument to be recognized immediately in earnings causing earnings volatility. Although, SFAS's 133 "principal purpose of providing special accounting for hedging activities is to mitigate the effects on earnings of different existing recognition and measurement attributes" (SFAS 133,2008 , para. 366 , p. 130), the approach of accelerating the earnings recognition of hedges that do not comply for hedge accounting reproduces unrepresentative earnings volatility.

\section{References}

Adkis, C. L., Carter, A. D., \& Simpson, W. G., (2007). Managerial incentives and the use of foreign-exchange derivatives by banks. The Journal of Financial Research, 30(3), 399-413. https://doi.org/10.1111/j.1475-6803.2007.00220.x 
Allayannis, G., Rountree, B., \& Weston, J. (2008). Do investors value smooth performance? Journal of Financial Economics, 90(3), 237. https://doi.org/10.1016/j.jfineco.2008.02.002

Bank of America (2005). Summary Annual report and Form 10-K, Note 1: Summary of Significant Accounting Principles. Retrieved from http://www.bankofamerica.com/annualreport/2005/financial_review/40_note1.cfm

Barnes, R. (2001). Accounting for derivatives and corporate risk management policies. London Business School Accounting Subject Area No. 018. https://doi.org/10.2139/ssrn.298021

Beneda, N. (2013). The impact of hedging with derivative instruments on reported earnings volatility. Applied Financial Economics, 23(2), 165-179. https://doi.org/10.1080/09603107.2012.709599

Blamornsiri, S., Schroeder, G. R. (2004). The disclosure of information on derivatives under SFAS No. 133: Evidence from the Dow 30. Managerial Auditing Journal, 19(5), 669-680. https://doi.org/10.1108/02686900410537784

Boyabatli, O., \& Toktay, L. B. (2004). Operational hedging: A review with discussion. Research Collection Lee Kong Chian School of Business. Retrieved from https://ink.library.smu.edu.sg/lkcsb_research/3758

Bratten, B., Causholli, M. \& Khan, U. (2016). Usefulness of fair values for predicting banks' future earnings: evidence from other comprehensive income and its components. Review of Accounting Studies. 21(1), 280-315. https://doi.org/10.1007/s11142-015-9346-7

Campbell, J., Khan, U., \& Pierce, S. (2017). The Effect of Mandatory Disclosure on Market Inefficiencies: Evidence from Statement of Financial Accounting Standard Number 161. Columbia Business School Research Paper No. 17-94. https://doi.org/10.2139/ssrn.3035887

Chance, M. D., Brooks, R. (2007). An introduction to derivatives and risk management. Mason, OH: Thomspon.

Corman, L. (2006). Lost in the maze. CFO Magazine. Retrieved from http://www.cfo.com/article.cfm/6874855/1/c_8435337

Coughlan, G. (2003). Heat: A framework for evaluating hedge effectiveness. Journal of derivatives accounting, 1(2), 1-4. https://doi.org/10.1142/S0219868104000178

Drakopoulou V. (2015). The DOW 30's Compliance with the Provisions of SFAS 159 and 157 for Investments in Equity Securities. International Journal of Accounting Research, 3(118). https://doi.org/10.4172/ijar.1000118

FASB News Release. (07/24/07). FASB Issues Proposal to Clarify the "Shortcut Method" of Hedge Accounting. Norwalk, CT. Retrieved from http://www.fasb.org/news/nr072407.shtml

FASB Statement No. 133 and FASB Interpretation No. 45. FASB: Norwalk, CT. Retrieved from http://www.fasb.org/news/nr091208.shtml

Frestad, D., \& Beisland, L. A. (2015). Hedge Effectiveness Testing as a Screening Mechanism for Hedge Accounting: Does It Work? Journal of Accounting, Auditing \& Finance, 30(1), 35-56. https://doi.org/10.1177/0148558X14549457

Frestad, D., \& Beisland, L. A. (2015). Hedge Effectiveness Testing as a Screening Mechanism for Hedge Accounting: Does It Work? Journal Of Accounting, Auditing \& Finance, 30(1), 35-56. https://doi.org/10.1177/0148558X14549457

Géczy, C., Minton, A. B., \& Schrand, M. C. (2007). Taking a view: Corporate speculation, governance, and compensation. Journal of Finance, 62(5), 2405- 2443. https://doi.org/10.1111/j.1540-6261.2007.01279.x

Hariom, M., Spencer, P., \& Swaminathan, S. (2014). Is Hedge Accounting Designation Informative About How Firms Use Derivatives? Retrieved from SSRN: https://ssrn.com/abstract=2417194 or http://dx.doi.org/10.2139/ssrn.2417194

Hodder, D. L., Hopkins, E. P., \& Wahlem, M. J. (2006). Risk-relevance of fair-value income measures for commercial banks. Accounting Review, 81(2), 337-375. https://doi.org/10.2308/accr.2006.81.2.337

Hughen, L. (2010). When Do Accounting Earnings Matter More than Economic Earnings? Evidence from Hedge Accounting Restatements. Journal Of Business Finance \& Accounting, 37(9/10), 1027-1056. https://doi.org/10.1111/j.1468-5957.2010.02216.x 
Khan, U., Li, B., Rajgopal, S., \& Venkatachalam, M., (2018). Do the FASB's Standards Add Shareholder Value?. The Accounting Review, 93(2), 209-247. https://doi.org/10.2308/accr-51840

Kolbasovsky, L. (2009). The trade-off between risk management and earnings volatility: Evidence from restatements. Doctoral $\quad$ Dissertations. AAI3383915. Retrieved from https://opencommons.uconn.edu/dissertations/AAI3383915

Laeven, L., \& Levine, R. (2009). Bank governance, regulation and risk taking. Journal of Financial Economics, 93, 259-275. https://doi.org/10.1016/j.jfineco.2008.09.003

Lin, N. (2011). An Unintended Consequence of SFAS 133: Promoting Speculation. Journal Of Management Accounting Research, 23305-329. https://doi.org/10.2308/jmar-10068

Liu, Z., Seow, S. G., \& Xie, H. (2011). Does the accounting hedge ineffectiveness measure under SFAS 133 capture the economic ineffectiveness of a firm's hedging activities? (Working Paper). Retrieved from https://pdfs.semanticscholar.org/034f/567cebb7878f573a842aabb73d83cf9782ae.pdf

Makar, S., Wang, L. \& Alam, P. (2013). The mixed attribute model in SFAS 133 cash flow hedge accounting: implications for market pricing. Review of Accounting Studies, 18(1), 66-94. https://doi.org/10.1007/s11142-012-9201-Z

Muller, A., \& Verschoor, F. W. (2008). The value-relevance of foreign currency derivatives disclosures. SSRN Working Paper Series, 46. Retrieved from SSRN: http://papers.ssrn.com/sol3/papers.cfm?abstract_id=1091263 . http://dx.doi.org/10.2139/ssrn.1091263

Nan, L., (2007). Impact of SFAS 133 on speculation and hedging. Retrieved from SSRN: http://papers.ssrn.com/sol3/papers.cfm?abstract_id=1022346. doi:10.2139/ssrn.1022346

Office of the Comptroller of the Currency. (2005). Interagency advisory on accounting and reporting for commitments to originate and sell mortgage loans. Retrieved from http://www.federalreserve.gov/boarddocs/srletters/2005/SR0510a1.pdf

Pai, K. P., \& Curcio, J. R. (2005). Derivatives trading, "hedging,” and bank risk. Working Paper, University of Texas of the Permian Basin.

Panaretou, A., Shackleton, M., \& Taylor, P. (2009). Corporate risk management and hedge accounting (Working Paper). $\quad$ Retrieved from EFMA website: http://www.efmaefm.org/0EFMAMEETINGS/EFMA\%20ANNUAL\%20MEETINGS/2009-Milan/papers/Corp orate $\% 20$ Risk $\% 20$ Management $\% 20$ and $\% 20$ Hedge $\% 20$ Accounting.pdf

Park, J. (2005). The economic consequences of FAS-133 for bank holding companies. Bank Accounting and Finance, 18(6), 19-26. Retrieved from https:/cris.maastrichtuniversity.nl/ws/files/1582019/guid-79b654e5-09c1-498c-be6f-1aeb0be2be51-ASSET1.0

Sigrist, G. (2008). File Reference No. 1590-100: Proposed Statement of Financial Accounting Standards, Accounting for Hedging Activities, an amendment of FASB Statement No. 133. Morgan Stanley's Comment Letter No. 52 to FASB. from https://www.fasb.org/jsp/FASB/CommentLetter_C/ViewCommentLetter\&cid=1175803393165

Singh, A. (2008). The determinants of the decision to use financial derivatives in the lodging industry. Journal of Hospitality \& Tourism Research, 32(4), 423-447. https://doi.org/10.1177/1096348008321364

Spencer, S. (2018). Determinants and Consequences of Firms' Derivative Accounting Decisions. Retrieved from SSRN: https://ssrn.com/abstract=2685896 or http://dx.doi.org/10.2139/ssrn.2685896

Suh, W. J. (2007). The Economic Effects of SFAS 133 on Hedging Activities of Firms: Evidence from Oil and Gas Producers. Working Paper Stanford University

Thomas, S. (2018). Improving Financial Statement Footnotes: Evidence from Derivative and Hedging Disclosures. Retrieved from SSRN: https://ssrn.com/abstract=2739883 or http://dx.doi.org/10.2139/ssrn.2739883

Tromblem, A. M. (2003). Accounting for derivatives and hedging. New York, NY: McGraw-Hill.

Wang, X. (2005). Stock return dynamics under earnings management. Yale ICF Working Paper No. 06-01, 41. Retrieved from http://papers.ssrn.com/sol3/papers.cfm?abstract_id=870924

Will, F., (2002). Derivatives and hedging: an analyst's response to US FAS 133. WestLB Global Financial Markets IAS 39 Supplement. Retrieved from http://mitglied.multimania.de/frankwill/cf.pdf 
Zhang, H. (2009). Effect of derivative accounting rules on corporate risk management behavior. Journal of Accounting \& Economics, 47(3), 244-264. https://doi.org/10.1016/j.jacceco.2008.11.007

Zhou, H. (2009). Does fair value accounting for derivatives improve earnings quality? SSRN Working Paper Series, 25. Retrieved December 10, 2009, from Accounting \& Tax Periodicals. (Document ID: 1871162091).

\section{Note}

Note 1. Under the "short cut" method, if a company meets certain strict criteria, it permits the user to assume no ineffectiveness and then ongoing effectiveness testing is not required. If those criteria are not met in their entirety, companies must use the "long haul" method, which requires extensive documentation, analysis and testing at inception and during the life of the hedge. Bank of America determined that certain hedges did not qualify for hedge accounting under the "short cut" method. As a result, any fluctuations in the market value of the derivatives should have been recorded through the income statement with no corresponding offset to the hedged item. While the management of Bank of America believes most of these hedges would have qualified for hedge accounting under the "long haul" method, that accounting cannot be applied retroactively. Consequently, the restatement assumes hedge accounting was not applicable to these derivatives and the related hedged item during the periods under review. Bank of America continues to manage its economic exposure to possible changes in interest rates and foreign exchange values. During the first quarter, Bank of America will ensure that the hedges affected by the restatement qualify for hedge accounting under SFAS 133. The company has determined that it had certain weaknesses in internal controls relating to hedge accounting under SFAS 133 and it has remedied them. Source: http://www.prnewswire.com/news-releases/bank-of-america-to-restate-financial-statements-for-accountingunder-sfas-133-55395442.html

\begin{tabular}{|c|c|c|}
\hline Variable & Construct & Definition \\
\hline NOTIONAL & Notional Value & Aggregate total notional value of derivative contracts \\
\hline EVol & Earnings Volatility & $\begin{array}{l}\text { The average standard deviation of the ratio of total earnings before income taxes and } \\
\text { loan loss provisions to average total assets }\end{array}$ \\
\hline ESmooth & Earnings Smoothing & The ratio of loan loss provisions to net interest income \\
\hline ESmooth1 & Earnings Smoothing & $\begin{array}{l}\text { The ratio of the total notional value of derivatives used as hedging instruments } \\
\text { divided by total assets }\end{array}$ \\
\hline FINLEV & Financial Distress & $\begin{array}{l}\text { Tier } 1 \text { Leverage ratio defined as Tier } 1 \text { Capital divided by adjusted quarterly average } \\
\text { total assets after certain adjustments }\end{array}$ \\
\hline INFOASY & Information Asymmetry & The logarithm of the number of analysts following the firm each year \\
\hline UNDERC & Underinvestment Cost & $\begin{array}{l}\text { Market-to-book ratio computed as market value per share of common stock to book } \\
\text { value per share }\end{array}$ \\
\hline MNGRisk & Managerial Risk Aversion & Ratio of CEOs stock option-based compensation relative to total compensation \\
\hline CapAdeq1 & BHCs Capital Adequacy & $\begin{array}{l}\text { Tier } 1 \text { Capital which is Total Equity Capital minus (plus) accumulated net gains } \\
\text { (losses) on cash flow hedges. }\end{array}$ \\
\hline IRLIBOR & Interest Rate Coefficient & $\begin{array}{l}\text { The absolute value of the estimated coefficient from a regression of each BHCs } \\
\text { monthly stock returns on the monthly percentage change in LIBOR }\end{array}$ \\
\hline HEDGEINF $_{\text {CASHFLOE }}$ & Hedge Ineffectiveness & $\begin{array}{l}\text { Measures BHCs ineffective portion of the amount of gain (loss) recognized in } \\
\text { income on derivatives designated as cash flow hedges }\end{array}$ \\
\hline HEDGEINF FAIRVALUE & Hedge Ineffectiveness & $\begin{array}{l}\text { Measures BHCs ineffective portion of the amount of gain (loss) recognized in } \\
\text { income on derivatives designated as fair value hedges }\end{array}$ \\
\hline $\begin{array}{l}\text { ECOHEDGEGain } \\
\text { (Loss) }\end{array}$ & Economic Hedges & $\begin{array}{l}\text { Measures both realized and unrealized gains and losses recognized in income due to } \\
\text { changes in fair value of derivatives designated as economic hedges }\end{array}$ \\
\hline OCI & $\begin{array}{l}\text { Net Gains(Losses) reclassified } \\
\text { from OCI to Income }\end{array}$ & $\begin{array}{l}\text { OCI measures the net realized gains/losses reclassified from AOCI into income on } \\
\text { derivatives designated as cash flow hedges }\end{array}$ \\
\hline
\end{tabular}

